\title{
Pembelajaran Matematika dengan Metode Accelerated Learning untuk Meningkatkan Kemampuan Penalaran Adaptif Siswa SMP
}

\author{
Rizki Wahyu Yunian Putra ${ }^{1}$, Linda Sari ${ }^{2}$ \\ 1,2 IAIN Raden Intan: rizkiputra891@yahoo.com
}

\begin{abstract}
The aim of this research is to find out whether the improvement of students' adaptive reasoning ability with accelerated learning method is better than ordinary learning. This research is a quasi experiment or quasi-experimental design with pretest-posttest control group design. The sampling technique uses a class random technique. The implementation of this study was carried out on eighth grade students in one of the State Junior High Schools in Bandar Lampung. The questions given are questions of adaptive reasoning ability in relation and function material, the test of adaptive reasoning ability test is theoretically tested by the validator with the description that test questions can be understood well and empirically validity and reliability meet the characteristics to be used in research, the level of difficulty and distinguishing power of the problem can already be used to determine the improvement of adaptive reasoning abilities. Quantitative data analysis was carried out using a mean difference test and $\mathrm{N}$-Gain test. The results of this study were students whose learning to apply learning with the accelerated learning method improved adaptive reasoning ability was significantly better compared to students whose learning using ordinary learning was reviewed thoroughly.
\end{abstract}

Keywords: Accelerated Learning, adaptive reasoning ability.

\begin{abstract}
Abstrak
Tujuan pada penelitian ini adalah untuk mengetahui apakah peningkatan kemampuan penalaran adaptif siswa dengan metode accelerated learning lebih baik dari pembelajaran biasa. Penelitian ini merupakan penelitian quasi experiment atau eksperimen semu dengan rancangan pretest-posttest control group design. Teknik pengambilan sampel menggunakan teknik acak kelas. Pelaksanaan penelitian ini dilakukan pada siswa kelas VIII di salah satu SMP Negeri di Bandar Lampung. Soal-soal yang diberikan adalah soal-soal kemampuan penalaran adaptif pada materi relasi dan fungsi, uji coba tes kemampuan penalaran adaptif diuji secara teoritik oleh validator dengan gambaran bahwa soal tes dapat dipahami dengan baik dan secara empirik validitas dan reliabilitas memenuhi karakteristik untuk digunakan dalam penelitian, tingkat kesukaran dan daya pembeda soal sudah bisa digunakan untuk mengetahui peningkatan kemampuan penalaran adaptif. Analisis data kuantitatif dilakukan dengan menggunakan uji perbedaan rataan dan uji $N$-Gain. Hasil penelitian ini adalah siswa yang pembelajarannya menerapkan pembelajaran dengan metode accelerated learning peningkatan kemampuan penalaran adaptif secara signifikan lebih baik dibandingkan dengan siswa yang pembelajarannya menggunakan pembelajaran biasa ditinjau secara keselurahan.
\end{abstract}

Kata kunci: Accelerated Learning, kemampuan penalaran adaptif. 


\section{PENDAHULUAN}

Dalam proses pembelajaran diperlukan kemandirian dari siswa untuk mampu mengembangkan dan merumuskan ide-ide matematikanya. National Council of Teachers of Mathematics (NCTM) dalam (Effendi, 2012; Septian, 2014) menetapkan lima standar kemampuan matematis yang harus dimiliki oleh siswa, yaitu pemecahan masalah, komunikasi, koneksi, penalaran dan kemampuan representasi. Menurut Kilpatrick, Swafford dan Findell dalam (Aminah, 2015; Aristiyani \& Setyaningsih, 2013; Widjajanti, 2011) membutuhkan lima kemampuan matematis yang perlu dikembangkan yaitu pemahaman konseptual, kelancaran prosedur, kompetensi strategis, penalaran adaptif, dan disposisi produktif". Siswa dalam mempelajari matematika memerlukan penalaran untuk mencetuskan ide atau gagasanya dalam memecahkan masalah sehingga siswa dapat memahami konsep matematika yang benar (Bernard, 2015). Berdasarkan pra survey Peneliti melakukan wawancara dengan guru matematika yaitu Ibu Mutiarini, S. Pd didapat informasi bahwa kemampuan penalaran siswa dalam mempelajari matematika masih sangat rendah. Dalam proses pembelajaran masih menggunakan pembelajaran biasa, guru mendominasi dalam pembelajaran. Pada saat pembelajaran berlangsung hanya beberapa siswa saja yang aktif bertanya dan menjawab soal yang diberikan guru, siswa yang kurang aktif dalam proses pembelajaran cenderung mendengar dan mencatat yang disampaikan oleh guru sehingga pembelajaran hanya berjalan satu arah saja, sehingga dalam proses pembelajaran berlangsung kemampuan penalaran adaptif siswa masih belum terlihat.

Penalaran merupakan cara berpikir siswa yang logis secara pendekatan induktif yaitu pembelajaran memberikan bukti yang logis untuk mencapai kesimpulan dan pembelajaran deduktif yaitu konsep-konsep penyelesaian masalah yang berdasarkan penguasaan ilmu yang telah terbukti sehingga siswa dapat berpikir secara logis berdasarkan fakta yang ada untuk menarik kesimpulan (Bernard, 2015). Menurut Kilpatrick, Swafford dan Findell dalam (Aminah, 2015; Aristiyani \& Setyaningsih, 2013) menyatakan penalaran adaptif adalah kapasitas untuk berpikir secara logis, memperkirakan jawaban, memberikan penjelasan mengenai konsep dan prosedur jawaban yang digunakan dan menilai kebenarannya secara matematika. Kilpatrick dkk juga mengemukakan bahwa penalaran adaptif tidak hanya mencakup penalaran deduktif saja yang hanya mengambil kesimpulan berdasarkan pembuktian formal secara deduktif, tetapi penalaran adaptif juga mencakup intuisi dan penalaran induktif dengan pengambilan kesimpulan berdasarkan pola analogi, dan metofora. Berdasarkan pernyataan tersebut dapat diartikan bahwa penalaran adaptif memiliki cakupan yang lebih luas dibandingkan penalaran pada umumnya yang hanya mencakup penalaran induktif dan deduktif saja, karena dalam prosesnya penalaran adaptif juga melibatkan penalaran intuisi (Suhendra, Sugiatno, \& Suratman, 2016). Penalaran intuitif adalah penalaran yang mendasarkan suatu konklusi pada penampilan atau apakah perasaan benar (suatu asumsi) (Aminah, 2015). Penalaran adaptif tidak hanya menekankan siswa untuk menyelesaikan suatu permasalahan tetapi, siswa dituntut untuk berpikir secara logis 
yaitu masuk akal dan menggunakan penalarannya secara benar. Hal tersebut berdasarkan fakta yang diketahui sebelumnya, dan benar-benar mempertimbangkan bahawa prosedur penyelesainnya memang sesuai dengan kaidah yang berlaku.

Menurut Jeremy Kilpatrick dkk, siswa dapat menunjukan penalaran adaptif mereka ketika menemui tiga kondisi yaitu: 1) Mempunyai pengetahuan dasar yang cukup. Dalam hal ini siswa mempunyai kemampuan prasyarat yang bagus sebelum memasuki pengetahuan yang baru untuk menunjang proses pembelajaran; 2) Tugas yang dapat dipahami atau dimengerti dan dapat memotivasi siswa; 3) Konteks yang disajikan telah dikenal dan menyenangkan bagi siswa. Adapun indikator yang terdapat dalam penalaran adaptif yaitu: 1) mengajukan dugaan atau conjectur; 2) memberikan alasan mengenai jawaban yang diberikan; 3) menarik kesimpulan dari sebuah pernyataan; 4) memeriksa kesahihan suatu argumen; 5) menemukan pola dari suatu masalah matematika (Widjajanti, 2011). Beberapa penelitian tentang penalaran siswa telah dilakukan. Hasil penelitian oleh Sumarno dalam (Aminah, 2015) menemukan bahwa skor kemampuan siswa dalam pemahaman dan penalaran matematis masih rendah. Kemudian juga penelitian lainnya menyimpulkan kemampuan penalaran masih rendah menggunakan pembelajaran konvensional (Muharom, 2014; Utami, Mukhni, \& Jazwinarti, 2014). Sehingga sangat dibutuhkan pembelajaran yang tepat untuk mengakomodasi peningkatan kompetensi siswa sehingga hasil belajar dapat lebih baik khususnya kemampuan penalaran adaptif, salah satunya pembelajaran dengan metode Accelerated Learning.

Menurut Meier, model pembelajaran Accelerated Learning adalah "suatu model pembelajaran yang dapat mempercepat dan meningkatkan pembelajaran dengan cara mengajak siswa terlibat langsung dalam proses pembelajaran" (Suciutari, Wiarta, \& Putra, 2013). Accelerated Learning berfokus pada proses pembelajaran yang berlangsung cepat, menyenangkan dan memuaskan. Menyenangkan yang dimaksud adalah bangkitnya minat siswa dalam belajar, keterlibatan penuh siswa sehingga pembelajaran lebih bermakna (Adiguna, Suara, \& Semara, 2014; Parasti, Ngadino, \& Dwiji, 2012). Pembelajaran matematika merapkan metode Accelerated Learning telah dilakukan oleh (Aristiyani \& Setyaningsih, 2013; Putra, 2014; Suryaningtyas, 2014). Metode Accelerated Learning telah banyak juga dilakukan pembelajaran IPA oleh (Adiguna et al., 2014; Eskarina, Miharty, \& Thaib, 2015; Parasti et al., 2012; Rohman, 2012; Suciutari et al., 2013; Sugiarta, Widiana, \& Tastra, 2016; Sumarau \& Suherman, 2013; Taufiq \& Husna, 2016). Hasil penelitian menunjukan bahwa metode Accelerated Learning dapat digunakan dalam proses pembelajaran yaitu mampu berkontribusi positif dalam hal meningkatkan hasil belajar, prestasi belajar, aktivitas belajar, dan berpengaruh terhadap kemampuan matematis siswa seperti komunikasi matematis, kemampuan berpikir kritis, penguasaan konsep siswa.

Beberapa prinsip pokok Accelerated Learning menurut Meier yaitu: Keterlibatan total pembelajar dalam meningkatkan pembelajaran; belajar bukanlah mengumpulkan informasi secara fasif, melainkan menciptakan pengetahuan secara aktif; kerja sama di antara 
pembelajar sangat membantu meningkatkan hasil belajar; belajar berpusat aktivitas sering lebih berhasil daripada belajar berpusat prestasi, belajar berpusat aktivitas dapat dirancang dalam waktu yang jauh lebih singkat daripada waktu yang diperlukan untuk merancang pengajaran dengan prestasi (Adiguna et al., 2014). Metode Accelerated Learning dibagi menjadi enam langkah dasar yaitu: motivating your mind (memotivasi pikiran), acquiring the information (memberikan informasi), searching out the meaning (mencari tahu makna), triggering the memory (memicu memori), exhibition what you know (mepresentasikan apa yang diketahui), reflecting on how you have learned (merefleksikan apa yang telah dipelajari).

Beberapa penelitian telah dilakukan tentang metode Accelerated Learning dalam kegiatan pembelajaran berpengaruh nyata terhadap kemampuan berpikir kritis siswa (Fitriani, Indrowati, \& Karyanto, 2015), hasil belajar (Rafikasari, 2014; Suciutari et al., 2013) dan aktivitas belajar siswa (Rafikasari, 2014). Penelitian penerapan metode accelerated learning telah berhasil meningkatkan hasil belajar (Jainudin, 2014; Mukhta, 2014; Rohman, 2012), prestasi belajar (Eskarina et al., 2015), aktivititas siswa (Rohman, 2012) dan penguasaan konsep (Parasti et al., 2012) serta kemampuan komunikasi matematis siswa (Putra, 2014). Penelitian untuk mengukur kemampuan penalaran siswa juga telah dilakukan berbagai model atau metode seperti Pembelajaran Berbasis Masalah (Setiawan, 2015), model pembelajaran problem based learning dan Group Investigation (Aristiyani \& Setyaningsih, 2013) dan model kooperatif tipe Student Teams Achievement Division (STAD) (Muharom, 2014) serta pembelajaran Think Pair Square (Utami et al., 2014). Penelitian ini melakukan keterbaharuan menerapkan metode Accelerated Learning untuk mengukur kemampuan penalaran adaptif siswa. Dalam penelitian ini difokuskan pada tiga indikator, yaitu: 1) mengajukan dugaan atau conjectur; 2) memberikan alasan mengenai jawaban yang diberikan; 3) menemukan pola dari suatu masalah matematika. Peneliti hanya mengambil tiga indikator tersebut karena dari ketiga indikator tersebut sudah mencakup apa yang dimaksud pengertian penalaran adaptif menurut Kilpatrick, Swafford dan Findell, serta telah memenuhi indikator materi relasi dan fungsi.

Berdasarkan pada uraian latar belakang masalah, maka yang menjadi rumusan masalah dalam penelitian ini adalah: Apakah peningkatan kemampuan penalaran adaptif siswa dengan metode accelerated learning lebih baik dari pembelajaran biasa.

\section{METODELOGI PENELITIAN}

Metode penelitian ini menggunakan quasi experiment atau eksperimen semu terdiri dari dua kelompok penelitian yaitu eksperimen merupakan kelompok siswa yang pembelajarannya menerapkan pembelajaran dengan metode Accelerated Learning dan kontrol adalah kelompok siswa yang pembelajarannya tidak menerapkan pembelajaran dengan metode Accelerated Learning (biasa). Penelitian dilakukan di salah satu Sekolah Menengah Pertama Negeri di Bandar Lampung, populasi adalah seluruh siswa kelas VIII salah 
satu Sekolah Menengah Pertama Negeri di Bandar Lampung semester ganjil pada tahun ajaran 2016/2017. Pengambilan sampel dilakukan dengan teknik acak kelas yaitu mengambil sampel secara acak tanpa melihat kemampuan siswa yang terdapat di dalam kelas tersebut. Berdasarkan teknik tersebut diperoleh kelas VIII H sebagai kelas eksperimen (kelas yang memperoleh pembelajaran dengan metode accelerated learning) berjumlah 29 siswa dan kelas VIII J sebagai kelas kontrol (kelas yang memperoleh pembelajaran biasa) berjumlah 30 siswa dengan penimbang Wakil Kepala Sekolah dan guru sehingga total sampel seluruhnya berjumlah 59 siswa. Materi yang diajarkan adalah relasi dan fungsi.

Penulis mengumpulkan data untuk pengujian hipotesis sebanyak $4 x$ pertemuan kelas eksperimen dan $4 \mathrm{x}$ kelas kontrol. Untuk mengukur kemampuan penalaran adaptif siswa, penulis menggunakan pretest posttest control group design yaitu rancangan desain terdapat dua kelompok yang dipilih secara acak. Pelaksanaan penelitian dengan memberikan pretest sebelum pemberian perlakuan guna untuk mengetahui kondisi awal kemampuan penalaran adaptif siswa kelas eksperimen maupun kelas kontrol. Diakhir pertemuan setelah diberi perlakuan diberikan posttest guna untuk melihat hasil dari perlakuan yang telah diberikan.

Rancangan desain penelitian akan mengetahui apakah kemampuan penalaran adaptif siswa dengan pembelajaran accelerated laerning lebih baik dari pembelajaran biasa dilakukan penelitian dengan desain kelompok kontrol non-ekuivalen sebagai berikut:

\begin{tabular}{|llll|}
\hline $\mathrm{R}_{1}$ & $\mathrm{O}_{1}$ & $\mathrm{X}_{1}$ & $\mathrm{O}_{2}$ \\
$\mathrm{R}_{2}$ & $\mathrm{O}_{3}$ & $\mathrm{X}_{2}$ & $\mathrm{O}_{4}$ \\
\hline
\end{tabular}

Keterangan:

$\mathrm{R}_{1}=$ Kelompok ekperimen

$\mathrm{R}_{2}=$ Kelompok Kontrol

$\mathrm{X}_{1}=$ Perlakuan pembelajaran menggunakan metode accelerated learning

$\mathrm{X}_{2}=$ Perlakuan pembelajaran menggunakan metode ceramah (pembelajaran biasa)

$\mathrm{O}_{1}=$ Pretest Kelompok Eksperimen

$\mathrm{O}_{3}=$ Pretest Kelompok Kontrol

$\mathrm{O}_{2}=$ Posstest Kelompok Eksperimen

$\mathrm{O}_{4}=$ Posstest Kelompok Kontrol

Teknik analisis data dalam penelitian ini adalah uji statistik deskriptif dan uji inferensial. Uji deskriptif digunakan untuk mendeskripsikan nilai rata-rata, standar deviasi, gain dan $\mathrm{N}$-gain penalaran adaptif . Uji inferensial yang digunakan adalah uji normalitas dan uji homogenitas. Jika data terdistribusi normal dan homogen, uji hipotesis dilakukan dengan menggunakan uji t. 


\section{HASIL PENELITIAN DAN PEMBAHASAN}

Data kemampuan penalaran adaptif diperoleh melalui pre-test dan post-test, dan $\mathrm{N}$ gain. Berikut ini merupakan deskripsi pre-test, post-test, dan $\mathrm{N}$-gain pada kelas eksperimen dan kelas kontrol.

Tabel 1. Statistik Deskriptif Kemampuan Penalaran Adaptif

\begin{tabular}{ccccccccc}
\hline \multirow{2}{*}{ Nilai } & \multicolumn{4}{c}{ Eksperimen } & \multicolumn{6}{c}{ Kontrol } \\
\cline { 2 - 9 } & $\mathbf{N}$ & $\overline{\boldsymbol{x}}$ & SD & \% & $\mathbf{N}$ & $\overline{\boldsymbol{x}}$ & SD & $\%$ \\
\hline Pre-test & 30 & 38,103 & 14,965 & 38,1 & 29 & 39 & 16,26 & 39 \\
Post-test & 30 & 75,86 & 9,826 & 75,8 & 29 & 68,66 & 11,29 & 11,2 \\
N-gain & 30 & 0,624 & 0,006 & & 29 & 0,492 & 0,009 &
\end{tabular}

Skor Maksimum Ideal $=100$

Berdasarkan Tabel 1 di atas, diperoleh rataan pre-test untuk kelas eksperimen sebesar 38,103 dan untuk kelas kontrol sebesar 39. Rataan pre-test kedua kelas relatif sama sebelum diberikan perlakuan. Persentase skor diperoleh dari hasil bagi skor rataan dengan skor ideal dikali $100 \%$. Rataan skor post-test kemampuan penalaran adaptif pada kelas eksperimen adalah 75,86 lebih tinggi dari kelas kontrol dengan rataan post-test sebesar 68,66 . Rataan $N$ gain kemampuan penalaran adaptif pada kelas eksperimen adalah 0,624 dengan klasifikasi peningkatan sedang dan untuk kelas kontrol sebesar 0,492 dengan klasifikasi peningkatan sedang. Berikut secara ringkas disajikan perbandingan rataan skor pre-test, post-test, dan $\mathrm{N}$ gain kemampuan penalaran adaptif.

Tabel 2. Rataan Skor Pre-test, Post-test, dan N-gain Kemampuan Penalara Adaptif Siswa

\begin{tabular}{cccc}
\hline Kelas & Pre-test & Post-test & N-gain \\
\hline Eksperimen & 38,103 & 75,86 & 0,624 \\
Kontrol & 39 & 68,66 & 0,492
\end{tabular}

Dari Tabel 2 di atas tampak bahwa rataan pre-test kelas eksperimen dan kelas kontrol tidak jauh berbeda, nilai rataan kelas eksperimen 38,103 sedangkan kelas kontrol 39 yang menunjukkan bahwa kemampuan awal kedua kelas relatif sama sebelum diberikan perlakuan. Sedangkan untuk rataan post-test kelas eksperimen yang menerapkan pembelajaran dengan metode accelerated learning menunjukkan hasil yang lebih baik dengan nilai rataan 75,86 dibandingkan kelas kontrol yang mendapatkan pembelajaran biasa dengan nilai rataan 68,66 .

Analisis skor $\mathrm{N}$-gain kemampuan penalaran adaptif menggunakan data gain ternormalisasi, data gain ternormalisasi juga menunjukkan klasifikasi peningkatan skor siswa yang dibandingkan dengan skor maksimal idealnya. Rataan N-gain menggambarkan peningkatan kemampuan penalaran adaptif siswa yang menerapkan pembelajaran dengan metode accelerated learning maupun yang mendapat pembelajaran biasa. Rangkuman rataan $\mathrm{N}$-gain kemampuan penalaran adaptif siswa pada kelas eksperimen dan kelas kontrol disajikan dalam Tabel berikut. 
Tabel 3. Rataan dan Klasifikasi $\mathbf{N}$-gain Kemampuan Penalaran Adaptif

\begin{tabular}{ccc}
\hline Kelas & Rataan $\boldsymbol{N}$-gain & Klasifikasi \\
\hline Eksperimen & 0,624 & Sedang \\
Kontrol & 0,492 & Sedang
\end{tabular}

Dari Tabel 3 di atas terlihat bahwa siswa yang menerapkan pembelajaran dengan metode accelerated learning (kelas eksperimen) memiliki rataan skor $\mathrm{N}$-gain 0,624 sedangkan siswa yang mendapatkan pembelajaran biasa (kelas kontrol) memiliki rataan skor $\mathrm{N}$-gain 0 , 492. Hal ini menunjukkan bahwa peningkatan kemampuan penalaran adaptif siswa kelas eksperimen lebih baik atau lebih tinggi daripada kelas kontrol. Namun untuk menyakinkan apakah benar peningkatan kemampuan penalaran adaptif siswa yang menerapkan pembelajaran dengan metode accelerated learning lebih baik daripada siswa yang mendapatkan pembelajaran biasa perlu dilakukan uji statistik lanjutan.

Berdasarkan hasil uji normalitas didapat kesimpulan bahwa skor $N$-gain kelas eksperimen dan kelas kontrol berdistribusi normal, serta skor $\mathrm{N}$-gain kemampuan penalaran adaptif siswa kelas eksperimen dan kelas kontrol berasal dari varian yang homogen. Rangkuman hasil uji homogenitas $N$-gain pada taraf signifikansi $\alpha=0,05$ dapat dilihat pada tabel berikut ini:

Tabel 4. Hasil Uji Perbedaan Rataan Skor $\mathbf{N}$-gain Kemampuan Penalaran Adaptif

\begin{tabular}{ccccc}
\hline Kelompok & $\mathrm{N}$ & $\mathrm{F}_{\text {hitung }}$ & $\mathrm{F}_{\text {tabel }}$ & Keputusan \\
\hline $\begin{array}{c}\text { Eksperimen } \\
\text { Kontrol }\end{array}$ & 29 & 1,501 & 1,867 & $\mathrm{H}_{0}$ diterima \\
\hline
\end{tabular}

Berdasarkan hasil perhitungan tabel di atas diperoleh $F_{\text {hitung }}=1,501$ dan $F_{\text {tabel }}=1,867$ terlihat bahwa $F_{\text {hitung }}<F_{\text {tabel }}$. Kesimpulannya bahwa $\mathrm{H}_{0}$ diterima dan sampel berasal dari populasi yang homogen yang artinya peningkatan kemampuan penalaran adaptif siswa kelas eksperimen lebih baik daripada siswa kelas kontrol, dengan demikian terbukti bahwa hipotesis yang menyatakan bahwa peningkatan kemampuan penalaran adaptif siswa yang menerapkan pembelajaran dengan metode accelerated learning lebih baik daripada siswa yang mendapatkan pembelajaran biasa. Pengujian hipotesis dengan kesamaan dua rata-rata, dengan uji-t parametrik. Rangkuman hasil uji hipotesis $N$-gain pada taraf signifikansi $\alpha=0,05$ pada tabel berikut ini:

Tabel 5. Hasil Uji Hipotesis $\mathbf{N}$-gain Kemampuan Penalaran Adaptif

\begin{tabular}{cccccc}
\hline Kelompok & Rata-rata & Varians & $t_{\text {hitung }}$ & $t_{\text {tabel }}$ & Keputusan \\
\hline Eksperimen & 0,624 & 0,006 & 5,662 & 2,002 & $H_{0}$ ditolak \\
Kontrol & 0,492 & 0,009 & & & \\
\hline
\end{tabular}


Berdasarkan uji hipotesis $N$-gain kemampuan penalaran adaptif pada materi relasi dan fungsi dapat dilihat bahwa thitung $=5,662>t_{\text {tabel }}=2,002$ ini berarti pada taraf signifikasi $\alpha=$ $0,05 \mathrm{H}_{0}$ ditolak. Artinya rata-rata kemampuan penalaran adaptif dengan menggunakan metode pembelajaran accelerated learning lebih besar daripada rata-rata kemampuan penalaran adaptif dengan menggunakan pembelajaran biasa yang menunjukkan bahwa kemampuan penalaran adaptif siswa dengan metode pembelajaran accelerated learning lebih baik dari pembelajaran biasa. Hasil penelitian ini didukung oleh penelitian Jaya Dwi Putra dengan kesimpulan peningkatan kemampuan komunikasi matematis siswa yang mendapat pembelajaran accelerated learning lebih baik daripada siswa yang mendapat pembelajaran konvensional atau biasa (Putra, 2014). Penelitian lain yang mendukung telah dilakukan oleh Edo Bawono bahwa metode accelerated learning menjadi salah satu metode pembelajaran yang dapat digunakan dalam pembelajaran matematika karena dapat meningkatkan kemampuan pemahaman matematik (Bawono, 2015).

\section{SIMPULAN DAN SARAN}

Berdasarkan pembahasan, dapat disimpulkan bahwa siswa yang pembelajarannya menerapkan pembelajaran dengan metode accelerated learning peningkatan kemampuan penalaran adaptif secara signifikan lebih baik dibandingkan dengan siswa yang pembelajarannya menggunakan pembelajaran biasa ditinjau secara keselurahan.

\section{DAFTAR PUSTAKA}

Adiguna, I. K. C., Suara, I. M., \& Semara, N. (2014). Pengaruh Model Pembelajaran Accelerated Learning Mind Mapping Terhadap Hasil Belajar IPA siswa kelas V SD no . 2 Tuban. MIMBAR PGSD Undiksha, 2(1).

Aminah, N. (2015). Kemampuan Komunikasi dan Penalaran Matematis pada Perkuliahan Kapita Selekta Matematika. ALPHAMATH, 1(1).

Aristiyani, A., \& Setyaningsih, N. (2013). The Implementation of Problem Based Learning Model Through Group Investigation in Mathematics Learning Viewed from Student's Adaptive Reasoning in SMP Negeri 1 Surakarta. Prosiding Seminar Nasional Pendidikan Matematika Surakarta 2013, (3), 40-46.

Bawono, E. (2015). Pengaruh Metode Accelerated Learning Berbantu Jurnal Belajar Dan Geogebra 3d Ditinjau Dari Kemampuan Pemahaman Matematik Terhadap Hasil Belajar Pada Ruang Dimensi Tiga. AKSIOMA: Jurnal Matematika Dan Pendidikan Matematika, 6(3), 69-77.

Bernard, M. (2015). Meningkatkan kemampuan komunikasi dan penalaran serta disposisi matematik siswa smk dengan pendekatan kontekstual melalui game adobe flash cs 4.0. Infinity, 4(2), 197-222. 
Effendi, L. A. (2012). Pembelajaran Matematika Dengan Metode Penemuan Terbimbing Untuk Meningkatkan Kemampuan Representasi Dan Pemecahan Masalah Matematis Siswa Smp. Jurnal Penelitian Pendidikan, 1-10.

Eskarina, E., Miharty, \& Thaib, A. (2015). Penerapan Model Pembelajaran Kooperatif Accelerated Learning untuk Meningkatkan Prestasi Belajar Siswa pada Pokok Bahasan Hidrokarbon Di Kelas XI IPA SMA Negeri 6 Pekanbaru. Jurnal Online Mahasiswa Fakultas Keguruan Dan Ilmu Pendidikan Universitas Riau, 2(1), 1-9.

Fitriani, A., Indrowati, M., \& Karyanto, P. (2015). Student's Critical Thinking Skill On Biology Learning Through The Implementation Of Accelerated Learning A Case Study Of X Grade Students SMA Negeri Karangpandan Karanganyar. Jurnal Pendidikan Biologi Universitas Sebelas Maret, 7(2).

Jainudin, N. (2014). Meningkatkan Hasil Belajar Siswa Kelas VI Pada Pelajaran PKn Di SDN SN Sungai Miai 7 Banjarmasin Utara Melalui Metode Pembelajaran Accelerated Learning. Disertasi Dan Tesis Program Pascasarjana UM.

Muharom, T. (2014). Pengaruh Pembelajaran Dengan Model Kooperatif Tipe Student Teams Achievement Division (Stad) Terhadap Kemampuan Penalaran Dan Komunikasi Matematik Peserta Didik Di SMK Negeri Manonjaya Kabupaten Tasikmalaya. Jurnal Pendidikan Dan Keguruan Vol., 1(1).

Mukhta, A. (2014). Penerapan Metode Accelerated Learning Menggunakan Langkah M-a-s-te-r untuk meningkatkan Hasil Belajar Siswa pada Pokok Bahasan Hidrokarbon di SMAN 2 Siak Hulu Kabupaten Kampar. Skripsi Thesis, Universitas Islam Negeri Sultan Syarif Kasim Riau.

Parasti, N., Ngadino, \& Dwiji. (2012). Model Accelerated Learning Meningkatkan Penguasaan Konsep IPA Materi Alat Indra. Jurnal Didaktika Dwija Indria, 2(3).

Putra, J. D. (2014). Penerapan Accelerated Learning Dalam Peningkatan Kemampuan Komunikasi Matematis Siswa Sekolah Menengah Pertama. Jurnal Dimensi, 3(3).

Rafikasari, R. (2014). Penerapan Pendekatan Accelerated Learning dengan Modalitas Otak Terhadap Aktivitas dan Hasil Belajar Siswa (Siswa Kelas VIII SMP Negeri 9 Jember). Undergraduate Theses Univeristas Jember.

Rohman, M. (2012). Penerapan Pembelajaran Accelerated Learning dengan Media Piktogram untuk Meningkatkan Hasil Belajar Biologi Kelas VII SMP Negeri 1 Bangsalsari Tahun Ajaran 2008/2009. BIOSHELL, 1(1)., 1(1).

Septian, A. (2014). Pengaruh Kemampuan Prasyarat terhadap Kemampuan Penalaran Matematis Mahasiswa dalam Matakuliah Analisis Real. ATIKAN: Jurnal Kajian Pendidikan, 4(2), 179-188.

Setiawan, S. (2015). Peningkatan Kemampuan Penalaran Matematis Siswa Melalui 
Pembelajaran Berbasis Masalah. ITQAN: Jurnal IImu-IImu Kependidikan, 6(2), 1-16.

Suciutari, N. P. D., Wiarta, 1 Wy, \& Putra, M. (2013). Model Pembelajaran Accelerated Learning Berfasilitas Multimedia Berpengaruh Terhadap Hasil Belajar IPA Siswa Kelas V SD Gugus III Kecamatan Semarapura. MIMBAR PGSD Undiksha, 1(1).

Sugiarta, G. P. O., Widiana, I. W., \& Tastra, I. D. K. (2016). Penerapan Model Pembelajaran Akselerasi (Accelerated Learning) Untuk Meningkatkan Hasil Belajar IPA Siswa Kelas V di SD N 8 Banyuning. MIMBAR PGSD Undiksha, 6(3), 1-10.

Suhendra, D., Sugiatno, \& Suratman, D. (2016). Potensi Penalaran Adaptif Matematis Siswa Dalam Materi Persamaan Garis Lurus di Sekolah Menengah Pertama. Jurnal Pendidikan Dan Pembelajaran, 5(6), 1-13.

Sumarau, N. I. A., \& Suherman. (2013). Pengaruh Pembelajaran Metode Accelerated Learning Terhadap Hasil Belajar Siswa Kelas XI IPA Man I Palu pada Pokok Bahasan Laju Reaksi. Jurnal Akademika Kimia, 2(1), 25-30.

Suryaningtyas, A. (2014). Peningkatan Aktivitas Belajar Matematika Siswa melalui Strategi Pembelajaran Accelerated Learning Berbasis Power Point bagi Siswa Kelas VII SMP Negeri 2 Ngemplak Boyolali Tahun 2013/2014. Skripsi Thesis, Universitas Muhammadiyah Surakarta.

Taufiq, M., \& Husna, K. (2016). Penerapan Model Pembelajaran Accelerated Learning untuk Meningkatkan Hasil Belajar Siswa Kelas X SMA Negeri 1 Dewantara Pada Konsep Hukum Newton. Jurnal Pendidikan Almuslim, 1(1).

Utami, N. P., Mukhni, \& Jazwinarti. (2014). Kemampuan Penalaran Matematis Siswa Kelas XI IPA SMAN 2 Painan Melalui Penerapan Pembelajaran Think Pair Square. Jurnal Pendidikan Matematika, 3(1), 7-12.

Widjajanti, D. B. (2011). Mengembangkan Kecakapan Matematis Mahasiswa Calon Guru Matematika Melalui Strategi Perkuliahan Kolaboratif Berbasis Masalah. Prosiding Seminar Nasional Penelitian, Pendidikan Dan Penerapan MIPA. Fakultas MIPA Universitas Negeri Yogyakarta., 1-7. 